Such narrative has no climax, with a fact of breaking free just being stated. The accent is shifted to denouement: She ran away and was picked up .... Today, she's a brilliant poet and spoken word artist ... [2]. A victim's life is broken into past and present, with her future being vague: "In my eyes, everything was ruined and just burning." Today, Lowyal is back at school...» [2].

This sequence of events constitutes a typical scenario in the human trafficking representation in social campaign underlying the survival storytelling technique. The results are valuable for an empirical research aimed verifying reader's response to the human trafficking survivor stories.

\title{
References:
}

1. Paliichuk E. Storytelling in English-Language Anti-Trafficking Campaign: A Cognitive Perspective. Studia Philologica. 2018. No.2 (11). P. 100-106. DOI: https://doi.org/10.28925/2311-2425.2018.11.16

2. Equality Now. A Just World for Women and Girls. URL: https://www.equalitynow.org/stories_of_survivors (Retrieved on 16 February 2021)

3. Langacker, R.W. Foundations of Cognitive Grammar. Theoretical Prerequisites. Stanford: Stanford University Press, 1987. V. 1. 516 p.

4. Mills, P. The Routledge Creative Writing Coursebook. London and New York: Routledge. 2006. 256 p.

DOI https://doi.org/10.30525/978-9934-26-039-1-84

\section{ПСИХОЛІНГВІСТИЧНІ ОСОБЛИВОСТІ ТЕКСТІВ КНИЖКОВИХ АНОТАЦІЙ}

\author{
Полтавець Ю. С. \\ кандидат філологічних наук, \\ старший викладач кафедри журналістики \\ факультету української філології та літературної творчості \\ імені Андрія Малишка
}

Начіонального педагогічного університету імені М. П. Драгоманова м. Київ, Украӥна

Книжкові анотації є важливим засобом комунікації між видавництвом і читачами. Вони формують образ видання у свідомості потенційних читачів, і щоб він був позитивним та щоб в адресата виникла потреба 106 
придбати книгу, видавці вдаються до різноманітних мовних засобів впливу на раціональну та емоційну сфери психіки читача. Поза увагою дослідників залишаються, на відміну від лінгвопрагматичних i комунікативних $[1 ; 2 ; 4]$, психолінгвістичні особливості анотацій, що й зумовлює актуальність цієї розвідки. Мета дослідження - з'ясувати специфіку психологічного впливу текстів анотацій через мовностилістичні й змістові засоби на адресата мовлення (на матеріалі видавничих і рекламних анотацій до сучасних книжкових видань художньої, навчальної та нон-фікшн літератури).

Серед мовленнєвих тактик, які ефективно впливають на свідомість потенційного читача, заслуговують на увагу тактики аргументування $\mathrm{i}$ позиціонування. Сильними аргументами є факти, зокрема ті, що подають цифрові значення: Книжка 24 місяиі перебувала в списку бестселерів BusinessWeek. Вона названа книжкою року в кількох рейтингах та обрана однією зі 100 найкращих бізнес-книжок усіх часів (Хіз Ч., Хіз Д. «Приліпи. Ефективність ідей: чому одні досягають успіху, а інші зазнають невдач», 2016).

Позиціонування - це забезпечення товару конкурентоспроможного становища на ринку й у свідомості споживачів. Видання в анотаціях позиціонується видавцем (або продавцем) як:

1. визначний твір:

1.1. перевірений часом: Комедії Вільяма Шекспіра (1564-1616), найвидатнішого англійського драматурга, вже понад чотири століття захоплюють читачів та з успіхом ідуть на сценах кращих театрів світу (В. Шекспір, «Багато галасу з нічого. Комедія помилок», 2018), Як і сам портрет, иінність иьього роману непідвладна часу (О. Уайльд, «Портрет Доріана Грея. Золота Полиця», 2018), Чорний Красень - вороний кінь благородної крові з білою зірочкою на лобі. Книжка про його дивовижні пригоди побачила світ понад 100 років тому в Англії $і$ з того часу стала улюбленою для багатьох поколінь, а за ї̈ сюжетом знято знаменитий фільм (Анна Сюел, «Чорний Красень», 2017),

1.2. оцінений багатьма читачами: До чергового тому твоєї улюбленої серії увійшла казкова повість Джеймса Метью Баррі «Пітер Пен», яка полюбилася мільйонам маленьких читачів (Дж. Баррі, «Пітер Пен», 2016),

1.3. оцінений відомими особистостями (прийом тестимоніалу): До нього рано прийшло визнання: прочитавщи «Гофманову ніч», перед молодим автором став на коліна сам метр Микола Хвильовий (В. Агеєва, «Візерунок на камені. Микола Бажан. Життєпис (не)радянського поета», 2018), 
1. оцінений фахівцями (має нагороди на літературних конкурсах): «Село не люди» - лауреат конкурсу романів, кіносиенаріїв та n'єс «Коронація слова - 2007» (Люко Дашвар, «Село не люди», 2008);

2. твір видатного письменника: Джейн Остен (1775-1817) i досі по праву вважається «першою леді» англійської літератури. Ї̈ «романи звичаїв» підкоряють ось уже трете століття щзирістю, тонким психологізмом, істинно англійським гумором $i \epsilon$ обов'язковими для вивчення в коледжах і університетах Великої Британії (Дж. Остін, «Гордість і упередженість», 2018);

3. як один $з$ кращих чи найкращий твір певного письменника, доби, напряму: «До маяка» - один із найвідоміших романів британської письменниці, яскравої представниці модерністської прози Вірджинї Вулф (1882-1941) (В. Вулф, «До маяка», 2017). Реалізується через порівняння: використання найвищої форми порівняння прикметника: Одне з найвидатніших досліджень німецького кіно (3. Кракауер «Від Калігарі до Гітлера - психологічна історія німецького кіна», 2009), Знаменитий роман «Портрет Доріана Грея» - найуспішніша й найскандальніша з усіх створених Оскаром Уайльдом книг. (О. Уайльд, «Портрет Доріана Грея. Золота Полиця», 2018), Часто кажуть, що перша книжка письменника $є$ найщирішою, бо саме в ній він відкривається повністю. «Кілер+» - із таких книжок (А. Любка, «Кілер+», 2018) та зіставлення: Збірка «Пісня Пісень» апелює назвою до відомої книги Старого Завіту, тим самим натякаючи, щу перед читачами - одна із можливих сучасних ї̈ версій (Б. Матіяш, «Пісня Пісень», 2018);

4. як видання, що $є$ першим на ринку (відповідної тематики, змістового наповнення, оформлення тощо): У изій книжиі вперще зібрані під однією обкладинкою вірші для дітей відомого поета Івана Андрусяка (I. Андрусяк, «М'яке і пухнасте», 2010), Це видання - перша книга вибраних творів самобутнього письменника, класика украӥнської літератури в перекладах білоруською (Б.-І. Антонич, «Зелене Євангелія» Упоряд. Р. Лубківського і В. Рагойші, 2011);

5. як єдине чи унікальне видання за певним критерієм: Це видання своєрідне і унікальне: збірка літературно-художніх творів і практичний посібник з лікування кольором (Н. Іванюк «Кольорові казки», 2010).

На психологію сприйняття тексту безпосередньо впливає його обсяг. Відповідно до державних стандартів України обсяг анотації становить 500-600 символів, відповідно до інструкцій Amazon 3 опису книг приблизно 150 слів. Радять уникати деталей, щоб не заплутати читача, адже він тільки кілька секунд вирішує, чи варто йому продовжувати 
ознайомлення 3 книгою. Більшість проаналізованих анотацій має саме такий обсяг, хоч інколи видавці нехтують цією вимогою, і тоді маємо завеликі або ж замалі (наприклад, одне загальне речення) анотації, що зумовлює комунікативну невдачу.

Антиципація як психологічний механізм пізнавальної діяльності людини виникає під час опрацювання будь-якого тексту, але стосовно текстів анотацій важливими $є$ такі особливості: по-перше, адресат повідомлення прогнозує основні змістові елементи повідомлення (інформація про автора, тема, ідея книги), його структуру, по-друге, адресат передбачає намір адресанта - похвалити видання, переконати його придбати. В отримувача повідомлення з одного боку є потреба в інформації про видання, а з іншого - $\epsilon$ упередження ставлення до тексту анотації як реклами.

3 огляду на цю особливість сприйняття анотації заслуговують на увагу формулювання «тут ви не знайдете», «книга не для вас», «книга не гарантує». Наприклад: Якщо ти «зірка універу», завжди знаєш, чого хочеш, і успішна у всьому, якщо тобі незнайомі невпевненість $і$ сумніви, тоді розслабся - ия книжка не для тебе (Андерсен С. «Це серйозно! Антидепресивна книжка для дівчат», 2016). Хоч далі в тексті й зазначено, для кого книга (Сара Андерсен, молода художниия з Брукліна, адресувала ї̈ всім іншим дівчатам. Тим, хто може витратити иілі вихідні на сидіння в Інтернеті. Хто безперервно мріє - повернутися додому $і$ влізти в улюблену піжаму), але свою функцію в анотації такий вислів виконує - він має на меті не виправдати очікування адресата, не підтвердити шаблон клішованими висловами «ця книга для вас», «книга порадує, навчить, допоможе...». Крім цього, формулювання «Якщзо ти «зірка універу», завжди знаєш, чого хочеш, і успішна у всьому, якщо тобі незнайомі невпевненість $i$ сумніви» апелює до рівня самоідентифікації особистості, що забезпечує сильний психологічний вплив на адресата.

Сприйняття тексту залежить і від його графічного втілення. Легко сприймається і переконливо діє на читача подання інформації у вигляді списків, переліку. У друкованих прикнижкових анотаціях такий спосіб не практикується, а от інтернет-книгарні до нього вдаються:

-6 прийомів, завдяки яким ви станете справжнім майстром переговорів

- 16 тактик переконання з арсеналу успішних політиків і бізнесменів

- 116 прикладів із життя, які показують, наскільки легко ми стаємо жертвами чужого впливу (Р. Чалдині «Психологія впливу», 2019).

Агресивність/ дієслівність текстів більша в рекламних анотацій, ніж у видавничих. Збільшується вона переважно за рахунок останніх 
спонукальних речень з дієсловами наказового способу: Малюй та розмальовуй, надихайся шедеврами великих генї̈в та створюй власне! (Е. Ле Кер «Твоє життя в мистецтві», 2018).

Специфіка анотацій виявляється також в коефіцієнті емболії тексту, адже фактична інформація, а саме ім'я автора та назва видання, у деяких випадках може стає емболою, нерелевантними для читача відомостями. Сприйняття інформації читачем відбувається переважно від назви книги й імені автора до детальніших відомостей про неї: у випадку видавничої анотації інформація про автора і назва видання $\epsilon$ в бібліографічному описі, після якого розміщена анотація і який вона, власне, i доповнює, у випадку рекламної - ця інформація $є$ на передній сторінці обкладинки. Такі повтори, особливо, якщо назва твору громіздка, лише відбирають час у читача.

Отже, щоб книжкова анотація належно вплинула на потенційного читача, вона повинна мати невеликий обсяг, логічну структуру, бути інформативною і стилістично привабливою. Створювачам анотацій важливо показати сильні сторони видання, обрати таке позиціонування товару, за якого найповніше, найвдаліше будуть висвітлені його справжні переваги.

\section{Література:}

1. Годісь Ю. Я. Комунікативно-когнітивні засади мотиваційного жанру «мистецтво успіху» (на матеріалі англомовних текстів) : дис. ... канд. філол. наук. Львів, 2019. 253 с.

2. Дзикович О. В. Анотація-опис книги як вид рекламного тексту // Наукові записки Національного університету «Острозька академія». Серія: Філологічна. 2016. Вип. 61. С. 52-55.

3. Поцепцов Г. Г. Избранные труды по лингвистике / сост. Шевченко И.С. Винница: Нова Книга, 2013. 554 с.

4. Чуланова Г. В. Лінгво-прагматичні особливості тексту-регулятиву в рекламно-художньому дискурсі сучасної англійської мови : автореф. дис. ... канд. філол. наук. Донецьк, 2012. 20 с. 